\title{
Effect of Supplementary Cementitious Materials on Chloride Threshold and Corrosion Rate of Reinforcement
}

\author{
by Matthew O'Reilly, Omid Farshadfar, and David Darwin
}

Supplementary cementitious materials (SCMs) are commonly used as a means of reducing cost, reducing environmental impact, or reducing permeability of concrete, but the current field of research has found mixed results in terms of the resulting time to corrosion initiation and corrosion rate of concrete containing SCMs. This paper examines the time to corrosion initiation, the water-soluble critical chloride corrosion threshold, and the corrosion rate after initiation for uncracked concrete specimens containing cementitious material consisting of $100 \%$ portland cement, mixtures with volume replacements of cement by $20 \%$ and $40 \%$ Class C fly ash, $20 \%$ and $40 \%$ Grade 100 slag cement, and 5\% and 10\% silica fume. Specimens had $1 \mathrm{in}$. $(25 \mathrm{~mm})$ concrete cover and a watercementitious materials ratio $(\mathrm{w} / \mathrm{cm})$ of 0.45 .

Test results show that many specimens containing SCMs exhibited repassivation of the reinforcement after a "first" corrosion initiation. This "first" initiation occurred at chloride thresholds comparable to or lower than the chloride threshold for reinforcement in $100 \%$ portland-cement concrete. The reinforcement remained passive for varying lengths of time (from 3 to 50 weeks) before reinitiating. At reinitiation ("final" initiation), specimens with concrete containing SCMs exhibited times to corrosion initiation two to seven times that observed in specimens containing $100 \%$ portland cement and corrosion rates after initiation approximately an order of magnitude lower than that observed in specimens containing $100 \%$ portland cement. Increasing the amount of SCM generally lowered the corrosion rate after initiation. Chloride thresholds at final initiation for specimens containing fly ash or slag were 66 to 200\% higher than that observed for specimens containing $100 \%$ portland cement. Chloride thresholds at final initiation for specimens containing silica fume were 40 to $60 \%$ higher those observed for specimens containing $100 \%$ portland cement.

Keywords: chlorides; corrosion; fly ash; silica fume; slag cement; supplementary cementitious materials.

\section{INTRODUCTION}

Supplementary cementitious materials (SCMs) are widely used in structural concrete. SCMs lessen the environmental impact of concrete and may provide a less expensive alternative to portland cement. In addition, designers and owners are increasingly looking to SCMs as a means to improve the durability and service life of structures by creating a denser, less permeable concrete matrix.

Most research has shown that the partial replacement of cement with supplementary cementitious materials will increase the time to corrosion initiation. Hussain and Rasheeduzzafar (1994) reported that the partial replacement of cement with $30 \%$ fly ash approximately doubled the time to corrosion initiation. This delay in initiation results from decreased permeability due to a denser microstructure and a less porous interfacial transition zone between the cement matrix and aggregates (Mackechnie and Alexander 1996; Mangat et al. 1994). Fahim et al. (2017) evaluated uncracked concrete specimens exposed to a marine environment for 25 years and found that the use of fly ash, silica fume, or slag cement reduced the rate of chloride ingress and increased the time to corrosion initiation relative to mixtures containing $100 \%$ portland cement. Fahim et al. attributed this behavior to the increased resistivity of the concrete due to the use of SCMs. Bouteiller et al. (2012) showed that concretes with water-cementitious materials ratios $(w / \mathrm{cm})$ of 0.45 and 0.65 containing $70 \%$ slag cement were more resistant to chloride penetration than similar concretes containing only portland cement. Bouteiller et al. attributed the lower chloride ingress rate in the concretes containing slag cement to transport properties rather than the chloride binding capacity of slag cement.

Establishing time to initiation is useful for relative comparisons of concrete mixtures. To predict the impact of SCMs on service life in the field, however, accurate information is needed on the critical chloride corrosion threshold (quantity of chloride that causes steel to initiate corrosion) and the corrosion rate of reinforcement once the chloride threshold has been reached in concrete containing SCMs; here, the existing body of research has shown mixed results. Arya and Xu (1995) compared the quantity of bound chlorides with the corrosion rate in concrete containing portland cement, as well as concrete with either $65 \%$ slag cement, $35 \%$ fly ash, or $10 \%$ silica fume as a partial replacement of cement. Salt was admixed with the concrete at dosages of $1 \%$ and $3 \%$ by weight of cement to depassivate the reinforcing steel. For mixtures containing $1 \%$ chloride by weight of cement, the corrosion rate was the highest for specimens containing fly ash followed by specimens with silica fume and slag cement replacements, and portland cement without an SCM. For mixtures containing 3\% chloride by weight of cement, the specimens containing fly ash continued to have the highest corrosion rate, but now followed, highest to lowest, by specimens containing portland cement, slag cement, and silica fume. For the $1 \%$ chloride addition, Arya and $\mathrm{Xu}$ attributed the higher corrosion rate in concrete with SCMs to that in concrete with portland cement to the lower $\mathrm{pH}$ of the pore solution in the concrete containing the SCMs,

ACI Materials Journal, V. 116, No. 1, January 2019

MS No. M-2018-101, doi: 10.14359/51710968, was received March 23, 2018, and reviewed under Institute publication policies. Copyright (C) 2019, American Concrete Institute. All rights reserved, including the making of copies unless permission is obtained from the copyright proprietors. Pertinent discussion including author's closure, if any, will be published ten months from this journal's date if the discussion is received within four months of the paper's print publication. 
which resulted in depassivation of reinforcement at a lower chloride content. For the 3\% chloride addition, Arya and Xu believed the reduction of permeability caused by the addition of slag and silica fume controlled the corrosion rate. One disadvantage of the study by Arya and Xu, and all studies in which comparisons are made using mixtures containing admixed chlorides, is that a (usually unknown) portion of the chlorides will be bound in the hydration products and not available to cause corrosion. Thus, the results are more qualitative than quantitative.

Darwin et al. $(2011,2014)$ showed that cracks over reinforcing steel in concrete without SCMs subjected to chlorides result in earlier corrosion initiation and higher corrosion rates than in uncracked concrete, and found that a lower water-cement ratio $(w / c)$, which significantly reduced the permeability of the concrete, provided only limited corrosion protection in the presence of cracks. Scott and Alexander (2007) investigated the influence of SCMs on corrosion of reinforcing steel in cracked concrete but did not run similar tests on uncracked concrete. Portlandcement concrete and mixtures with replacements of $25 \%$ slag cement, $50 \%$ slag cement, $75 \%$ slag cement, $30 \%$ fly ash, or $7 \%$ silica fume, and a ternary blend with $50 \%$ portland cement, $43 \%$ slag cement, and $7 \%$ silica fume were tested. The specimens were cracked with three-point bending and exposed to cycles of ponding with a $5 \% \mathrm{NaCl}$ solution and drying at $85^{\circ} \mathrm{F}\left(30^{\circ} \mathrm{C}\right)$. Unlike the findings by Darwin et al. (2011, 2014) for concrete without SCMs and the findings by Arya and $\mathrm{Xu}$ for uncracked concrete with $\mathrm{SCMs}$, inclusion of any of the SCMs resulted in at least a $50 \%$ reduction in corrosion rate compared to mixtures with only portland cement. Similar results were observed by Pal et al. (2002), who studied reinforcement cast in uncracked concrete with $100 \%$ portland cement concrete as well as reinforcement in concrete containing 30,50 , and $70 \%$ slag. Specimens were exposed to a $3 \% \mathrm{NaCl}$ solution or placed in a salt spray chamber. Pal et al. found that the corrosion rate generally decreased as slag content increased, although a wide degree of scatter was observed. The previously referenced study by Fahim et al. (2017) found that reinforcement in concrete containing fly ash, silica fume, or slag exposed to a marine environment exhibited lower corrosion rates after initiation than reinforcement in $100 \%$ portland cement concrete.

Research on the effect of SCMs on the critical chloride corrosion threshold, like the research on corrosion rate, has yielded mixed results. Thomas (1996) showed that, although the mass loss of the steel embedded in the concrete containing fly ash exposed to a marine environment decreased with increasing fly ash content, the critical chloride threshold also decreased. Likewise, Oh et al. (2003) examined prismatic specimens with varying amounts of admixed chlorides and found that increasing the content of fly ash from 15 to $30 \%$ resulted in a decrease in the acid-soluble chloride threshold from 0.90 to $0.68 \%$ by weight of cementitious material and water-soluble chloride threshold from 0.11 to $0.07 \%$. Oh et al. also found that a $30 \%$ replacement of cement with slag cement had a negligible effect on the critical chloride threshold compared to that in portland cement concrete.
Presuel-Moreno and Moreno (2016) studied the critical chloride threshold and time to initiation for concrete specimens containing 20,35 , and $50 \%$ cement replacements by fly ash, as well as 6,15 , and $27 \%$ cement replacements by silica fume. Specimens were exposed to alternating cycles of 1 week of ponding with natural seawater and one week of drying. Among the specimens containing fly ash, those with $50 \%$ fly ash had the lowest critical chloride threshold and specimens with $35 \%$ fly ash had the highest; the specimens with 20 and 50\% fly ash had lower critical chloride thresholds than specimens containing portland cement only. Among the specimens containing silica fume, those with $6 \%$ silica fume had a comparable critical chloride threshold to specimens containing only portland cement; increasing silica fume content above $6 \%$ resulted in a decrease in the critical chloride threshold. Azad and Isgor (2016) examined the thermodynamics behind the chloride binding capacity of concrete containing SCMs and admixed chlorides and found that binding capacity decreased significantly at replacement levels above $20 \%$ for Class F fly ash, $30 \%$ for Class C fly ash, and $40 \%$ slag cement. A reduction in binding capacity would result in a greater percentage of chlorides in concrete being free chlorides, which in turn would decrease the total admixed chloride content corresponding to corrosion initiation.

Much of the evidence on the effect of SCMs on the critical chloride corrosion threshold and the corrosion rate of steel reinforcement in concrete has been obtained using admixed chlorides, as opposed to externally applied chlorides. Some of these studies have found a reduction in acid-soluble chloride threshold when SCMs are used, although the impact of any given SCM has not been consistent across studies. This this lack of clarity raises the necessity of further study of these effects. This study examined the effect of using SCMs (Class C fly ash, silica fume, and slag cement) as partial replacements of cement in concrete on the critical chloride corrosion threshold and corrosion rate of reinforcement in uncracked concrete. The corrosion performance of uncoated ASTM A615 bars in concrete containing these SCMs was evaluated and compared with concrete containing portland cement.

\section{RESEARCH SIGNIFICANCE}

The ability to accurately predict service life is of great importance to both owners and designers seeking to find cost-effective solutions to improve the durability of reinforced concrete structures. Doing so requires knowledge of the chloride threshold and the corrosion rate after initiation for reinforcement in concrete containing SCMs. This research seeks to provide insight into the behavior of reinforcement in concretes containing SCMs at and after initiation and provide more definitive values for the chloride threshold and corrosion rate.

\section{EXPERIMENTAL PROCEDURE}

To investigate the effect of SCMs on the corrosion performance of reinforcement, portland cement was partially replaced by SCMs so that the total mass of cementitious materials remained constant. For the mixtures containing 
Table 1-Mixture proportions (SSD basis)

\begin{tabular}{|c|c|c|c|c|c|c|c|c|c|}
\hline $\begin{array}{c}\text { Mixture } \\
\text { designation }\end{array}$ & $\begin{array}{l}\text { Mixture } \\
\text { type }^{*}\end{array}$ & $\begin{array}{c}\text { Cement, } \\
\mathrm{lb} / \mathrm{yd}^{3} \\
\left(\mathrm{~kg} / \mathrm{m}^{3}\right)\end{array}$ & 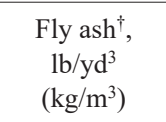 & $\begin{array}{l}\text { Silica fume }{ }^{\dagger} \text {, } \\
\mathrm{lb} / \mathrm{yd}^{3}\left(\mathrm{~kg} / \mathrm{m}^{3}\right)\end{array}$ & $\begin{array}{l}\text { Slag cement }{ }^{\dagger} \text {, } \\
\mathrm{lb} / \mathrm{yd}^{3}\left(\mathrm{~kg} / \mathrm{m}^{3}\right)\end{array}$ & $\begin{array}{l}\text { Water } \\
\mathrm{lb} / \mathrm{yd}^{3} \\
\left(\mathrm{~kg} / \mathrm{m}^{3}\right)\end{array}$ & $\begin{array}{c}\text { Coarse aggre- } \\
\text { gate }^{\dagger}, \mathrm{lb} / \mathrm{yd}^{3} \\
\left(\mathrm{~kg} / \mathrm{m}^{3}\right)\end{array}$ & $\begin{array}{c}\text { Fine } \\
\text { aggregate }^{\dagger}, \\
\mathrm{lb} / \mathrm{yd}^{3}\left(\mathrm{~kg} / \mathrm{m}^{3}\right)\end{array}$ & $\begin{array}{l}\text { Air-entraining } \\
\text { agent, oz } / \mathrm{yd}^{3} \\
\left(\mathrm{~mL} / \mathrm{m}^{3}\right)\end{array}$ \\
\hline PC & $100 \% \mathrm{PC}$ & $598(355)$ & - & - & - & $269(160)$ & $1484(880)$ & $1435(851)$ & $5.63(209)$ \\
\hline $\mathrm{FA}(20)$ & $20 \% \mathrm{FA}$ & $506.9(301.1)$ & $91.1(54.1)$ & - & - & $269(160)$ & $1484(880)$ & $1430(849)$ & $5.63(209)$ \\
\hline $\mathrm{FA}(40)$ & $40 \% \mathrm{FA}$ & $404.3(240.2)$ & $193.7(115.1)$ & - & - & $269(160)$ & $1484(880)$ & $1397(830)$ & $5.63(209)$ \\
\hline Slag(20) & $20 \%$ Slag & 487.5 (290) & - & - & 110.5 (65.6) & $269(160)$ & $1484(880)$ & $1450(858)$ & $5.63(209)$ \\
\hline Slag(40) & $40 \%$ Slag & $372.8(221.4)$ & - & - & $225.2(133.8)$ & $269(160)$ & $1484(880)$ & $1440(852)$ & $5.63(209)$ \\
\hline
\end{tabular}

${ }^{*} 100 \% \mathrm{PC}=$ mixture paste containing $100 \%$ portland cement; $20 \% \mathrm{FA}=$ mixture paste containing $20 \%$ fly ash and $80 \%$ portland cement by volume; $40 \%$ FA $=$ mixture paste containing $40 \%$ fly ash and $60 \%$ portland cement by volume; $20 \%$ Slag = mixture paste containing $20 \%$ Grade 100 slag cement and $80 \%$ portland cement by volume; $40 \%$ Slag $=$ mixture paste containing $40 \%$ Grade 100 slag cement and $60 \%$ portland cement by volume; $5 \%$ SF $=$ mixture paste containing $5 \%$ silica fume and $95 \%$ portland cement by volume; $10 \% \mathrm{SF}=$ mixture paste containing $10 \%$ silica fume and $90 \%$ portland cement by volume.

${ }^{\dagger}$ Specific gravity of fly ash $=2.3$; specific gravity of silica fume $=2.3$; specific gravity of slag cement $=2.9$; bulk specific gravity of fine aggregate $=2.63$; and bulk specific gravity of coarse aggregate $=2.59$.

\section{Table 2-Concrete properties}

\begin{tabular}{c|c|c|c|c|c}
\hline Mixture designation & Mixture type & Slump, in. $(\mathrm{mm})$ & Unit weight, $\mathrm{lb} / \mathrm{ft}^{3}\left(\mathrm{~kg} / \mathrm{m}^{3}\right)$ & Air content & Compressive strength, psi (MPa) \\
\hline PC & $100 \% \mathrm{PC}$ & $3(75)$ & $144.2(2310)$ & $5.6 \%$ & $4030(27.8)$ \\
\hline $\mathrm{FA}(20)$ & $20 \% \mathrm{FA}$ & $2-1 / 2(65)$ & $143.6(2300)$ & $5.1 \%$ & $4510(31.1)$ \\
\hline $\mathrm{FA}(40)$ & $40 \% \mathrm{FA}$ & $3-1 / 2(90)$ & $143.2(2293)$ & $5.6 \%$ & $4870(33.6)$ \\
\hline $\mathrm{SF}(5)$ & $5 \% \mathrm{SF}$ & $2(50)$ & $145.6(2332)$ & $5.4 \%$ & $4940(34.1)$ \\
\hline $\mathrm{SF}(10)$ & $10 \% \mathrm{SF}$ & $3(75)$ & $142.6(2284)$ & $5 \%$ & $4610(31.8)$ \\
\hline Slag(20) & $20 \% \mathrm{Slag}$ & $4(100)$ & $139.8(2239)$ & $6.6 \%$ & $4590(31.6)$ \\
\hline Slag(40) & $40 \% \mathrm{Slag}$ & $4(100)$ & $140.2(2245)$ & $6.7 \%$ & $4730(32.6)$ \\
\hline
\end{tabular}

Note: Slump, unit weight, air content, and compressive strength were measured in accordance with ASTM C143, C138, C231, and C39, respectively.

SCMs, $20 \%$ and $40 \%$ by volume of Class C fly ash, $20 \%$ and $40 \%$ by volume of Grade 100 slag cement, and $5 \%$ and $10 \%$ by volume of silica fume were used. The mixture proportions are provided in Table 1. All concrete mixtures had a $w / \mathrm{cm}$ of 0.45 , a target air content of $6 \pm 1 \%$, and a target slump of $3 \pm 1$ in. $(75 \pm 25 \mathrm{~mm})$. Plastic and hardened concrete properties for each mixture are tabulated in Table 2.

\section{Specimens}

The beam specimen used in this study is shown in Fig. 1. The specimens have dimensions of $12 \times 6 \times 7$ in. $(305 \times 152 \times$ $178 \mathrm{~mm}$ ) and two layers of No. 5 (No. 16) reinforcement, with one bar in the top mat and two bars in the bottom mat. The bars are 12 in. (305 mm) long with a 1 in. $(25 \mathrm{~mm})$ clear cover. The bottom bars are spaced at $2.5 \mathrm{in} .(64 \mathrm{~mm})$, and the top bar is centered within the prism. The specimens are cast upside down; to allow the specimens to be ponded with salt solution, a $0.75 \mathrm{in}$. $(19 \mathrm{~mm})$ concrete dam is cast integrally with the specimens.

Six specimens were cast for each concrete mixture. After casting, all specimens were wet-cured for 3 days and air-cured for 25 days thereafter. Ponding and lab tests began 28 days after casting. Prior to testing, the sides of the specimens were coated with an epoxy to protect the electrical connections and to prevent chloride ingress from the sides of the specimen. The top and bottom mats of reinforcement in each specimen were

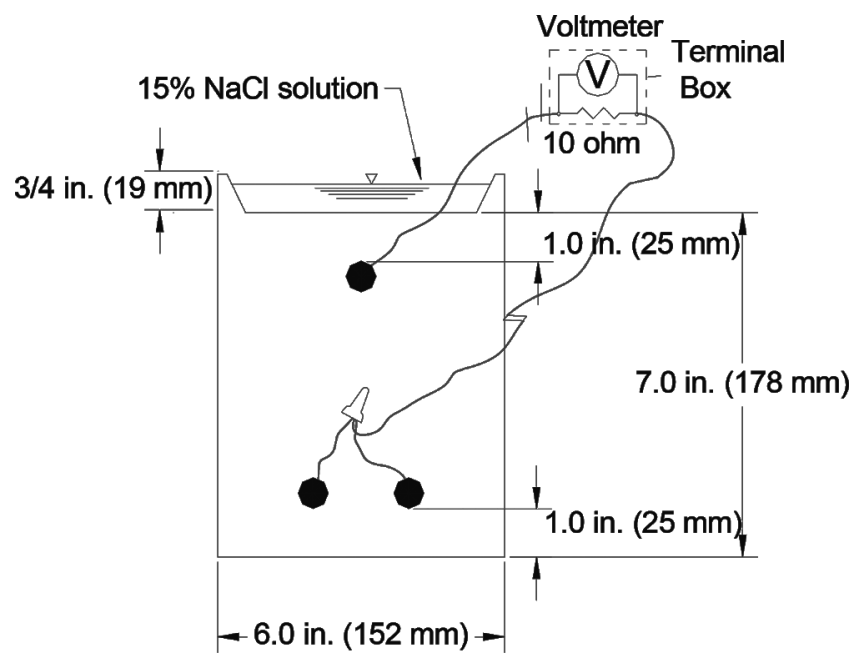

Fig. 1-Beam test specimen.

connected across a 10-ohm resistor via a terminal box to allow for determination of corrosion rate via voltage drop across the resistor, as explained in the following.

\section{Test procedure}

The test procedure followed the procedure for crackedbeam specimens in ASTM A955, and is summarized here. Specimens were exposed to alternating cycles of expo- 
sure: 12 weeks of wet-dry cycles followed by 12 weeks of continuously wet cycles. During the wet-dry cycles, the specimens were ponded with $300 \mathrm{~mL}$ of $15 \% \mathrm{NaCl}$ solution and maintained at ambient room temperature for 4 days. At this point, corrosion measurements including macrocell corrosion rate, corrosion potentials, and linear polarization resistance (LPR) were taken, the salt solution was vacuumed off the surface, and the specimens were placed under a heat tent at $100 \pm 3^{\circ} \mathrm{F}\left(38 \pm 2^{\circ} \mathrm{C}\right)$ for 3 days. This procedure was repeated for 12 weeks. After 12 weeks of wet-dry cycles, specimens entered a continuously wet cycle, where specimens were ponded continuously with $15 \% \mathrm{NaCl}$ solution and kept covered at ambient room temperature for 12 weeks. Deionized water was added to the ponding solution, as needed, to replace water lost due to evaporation. All readings were taken weekly except those for the LPR test, which were taken monthly.

\section{Chloride sampling and analysis}

As chlorides penetrate through concrete (or are admixed with it), a portion of the chloride ions bind with tricalcium aluminate $\left(\mathrm{C}_{3} \mathrm{~A}\right)$ in the cement matrix. These chlorides do not contribute to corrosion in their bound state but can be released if the $\mathrm{pH}$ of the concrete drops due to carbonation or other means. The acid-soluble chloride content of concrete includes these bound chlorides; the water-soluble chloride content does not. The chloride contents presented in this report are water-soluble chloride contents and are expressed as a mass of chloride per unit volume of concrete.

To determine the critical chloride corrosion threshold, the beam specimens were sampled upon corrosion initiation. Corrosion initiation was defined based on a macrocell corrosion rate exceeding $0.3 \mu \mathrm{m} /$ year and a corrosion potential more negative than $-0.275 \mathrm{~V}$ with respect to a saturated calomel electrode (SCE), equivalent to a corrosion potential of approximately $-0.350 \mathrm{~V}$ with respect to a copper-copper sulfate electrode (CSE).

Samples were taken using a 0.25 in. $(6.4 \mathrm{~mm})$ masonry drill bit such that the top of the bit was level with the top of the top mat of reinforcing steel (Fig. 2). Chloride samples were taken in concrete adjacent to the bar (as would be done in the field) as opposed to over the bar. Ten samples (five from each side) were taken upon onset of corrosion and six samples at the end of testing. At each sample site, concrete was initially drilled to a depth of $0.5 \mathrm{in} .(13 \mathrm{~mm})$ and the powdered concrete discarded. The drill was rinsed with deionized water and dried; the specimen was then drilled to a depth of 2.0 in. $(51 \mathrm{~mm})$ and the powdered sample (approximately $3 \mathrm{~g}$ ) transferred to a plastic bag for analysis. The drill bit was again cleaned with deionized water after the sample was taken. The holes left by sampling were then filled with modeling clay and the specimen returned to testing. The water-soluble chloride content of concrete samples was measured per AASHTO T 260-94.

\section{Corrosion measurements}

To obtain the macrocell corrosion rate, the voltage drop between the anode and cathode of each specimen was taken

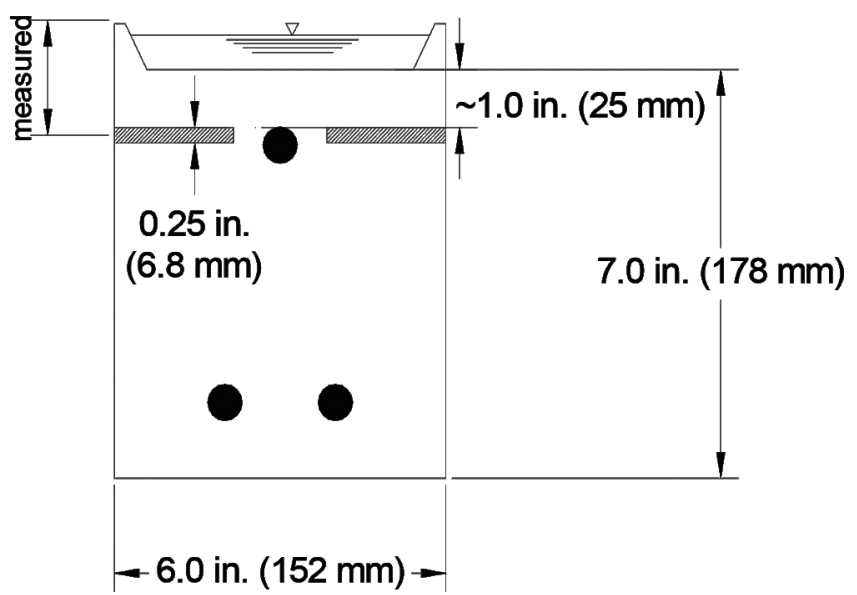

Fig. 2-Chloride sampling.

across a 10-ohm resistor. The current density on the anode was obtained using Ohm's Law

$$
i=10^{6} \times \frac{V}{R A}
$$

where $i$ is the current density $\left(\mu \mathrm{A} / \mathrm{cm}^{2}\right) ; V$ is the measured voltage drop across the resistor (volts); $R$ is the resistance of resistor ( $10 \mathrm{ohms}$ ); and $A$ is the surface area of the anode $\left(152 \mathrm{~cm}^{2}\right)$ - that is, the surface area of the top mat of steel in beam specimens.

The corrosion rate can be expressed as the thickness loss of steel per time. The relationship between current density and thickness loss can be expressed using Faraday's Law

$$
r=k \frac{i a}{n F \rho}
$$

where $r$ is the corrosion rate ( $\mu \mathrm{m} / \mathrm{year}) ; k$ is a conversion factor $(315,360$ (A. $\mu \mathrm{m} . \mathrm{s}) /(\mu \mathrm{A} . \mathrm{cm} . \mathrm{yr})) ; a$ is the atomic weight of the corroding metal $(55.85 \mathrm{~g} / \mathrm{mol}$ for iron); $n$ is the number of electrons lost per atom of metal oxidized ( 2 for iron); $F$ is Faraday's constant $(96,485$ Coulombs/ equivalent); and $\rho$ is the density of the metal $\left(7.87 \mathrm{~g} / \mathrm{cm}^{3}\right)$. By substituting proper values for iron, Eq. (2) simplifies to $r$ $=11.6 i$ in $\mu \mathrm{m} / \mathrm{yr}(0.457 i \mathrm{in} \mathrm{mils/yr})$.

After measuring the voltage drop, the connection between the anode and the cathode across the resistor was disconnected for at least 2 hours to allow the potentials to stabilize, and then the corrosion potential of the top and bottom mat in the beam specimens was measured using a saturated calomel electrode (SCE).

In addition to the weekly voltage drop and corrosion potential measurements, linear polarization resistance (LPR) was measured on a monthly basis. LPR data were used in subsequent determinations of corrosion rate after initiation.

Specimens that initiated corrosion prior to 96 weeks of testing were removed from testing at 96 weeks. Specimens that did not initiate corrosion by this age continued testing until after initiation with some remaining in the test through 164 weeks. 


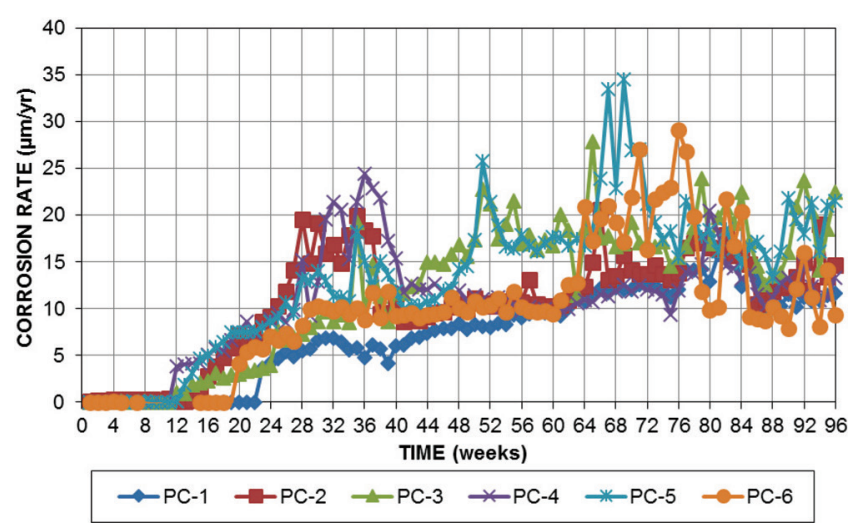

Fig. 3-Macrocell corrosion rates ( $\mu m / y r)$ for specimens containing conventional reinforcement and $100 \%$ portland cement.

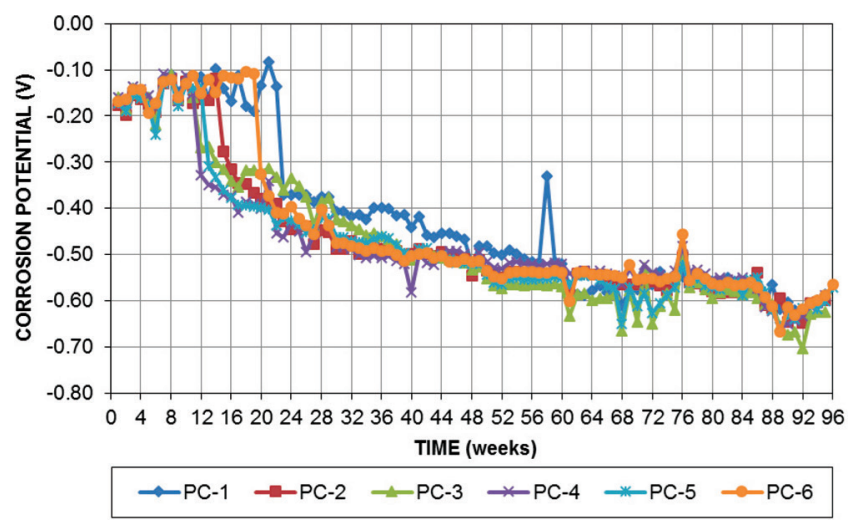

Fig. 4-Top mat (anode) corrosion potential (SCE) versus time for specimens containing conventional reinforcement and $100 \%$ portland cement.

\section{Corrosion initiation age}

\section{TEST RESULTS}

Figures 3 and 4 show the corrosion rate and top mat corrosion potential, respectively, for specimens with $100 \%$ portland cement concrete. For these specimens, there was a clearly defined point of corrosion initiation, with an increase in corrosion rate coupled with a decrease in potential. Once reinforcement in $100 \%$ portland cement concrete initiated, the bars did not repassivate. This behavior did not hold true for many specimens with concrete containing SCMs, however. Figures 5 and 6 show the corrosion rates and top mat corrosion potentials for specimens containing $10 \%$ silica fume $[\mathrm{SF}(10)]$. Specimen $\mathrm{SF}(10)-2$ initiated corrosion at an early age (19 weeks), but repassivated at week 40 . It then remained passive before reinitiating at week 66 . This behavior was observed in several specimens with concrete containing SCMs. Table 3 shows the initiation age for all specimens, with the term "First" initiation indicating that corrosion initiated but was followed by repassivation of the bar, and the term "final" initiation indicating that corrosion initiated and the bar did not repassivate. The age at repassivation is indicated in brackets.

As stated previously, reinforcement in concrete with $100 \%$ portland cement PC did not repassivate after initiation; the average initiation age for these specimens was 15.8 weeks. Repassivation and reinitiation were observed in one

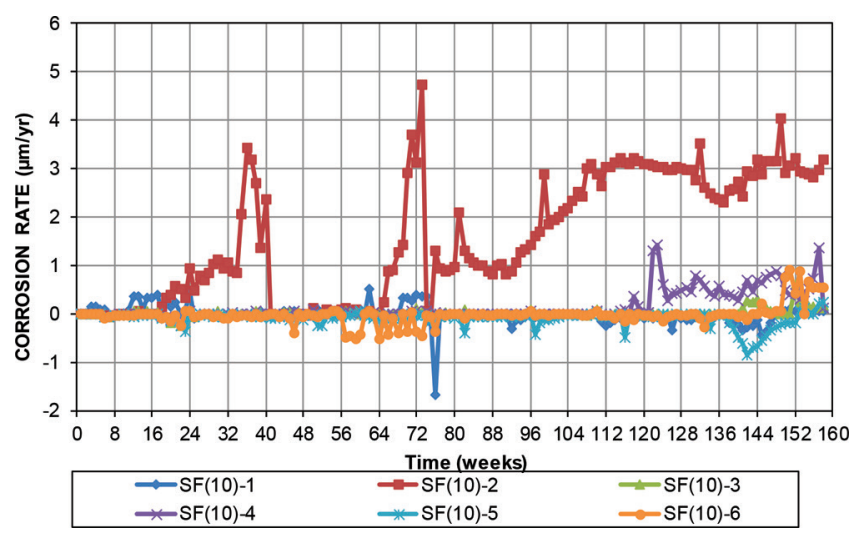

Fig. 5-Macrocell corrosion rates ( $\mu m / y r)$ for specimens containing conventional reinforcement and $10 \%$ silica fume.

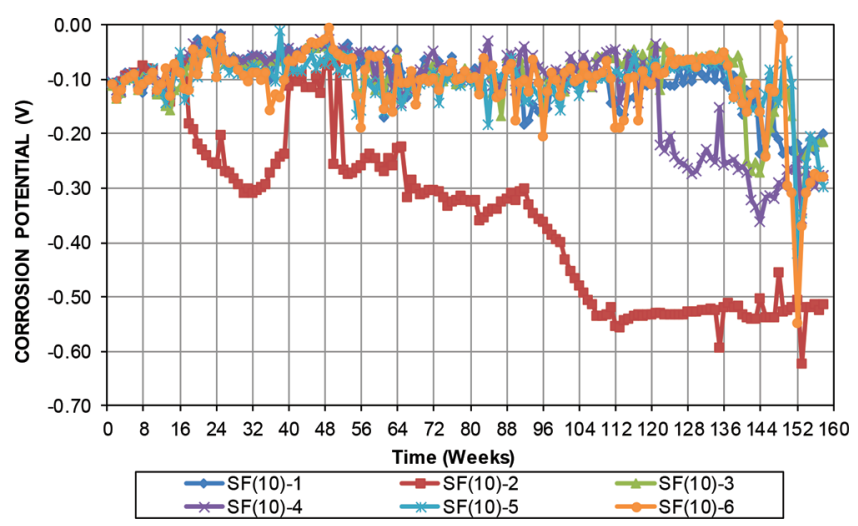

Fig. 6-Top mat (anode) corrosion potential (SCE) versus time for specimens containing conventional reinforcement and $10 \%$ silica fume.

of the six specimens with $20 \%$ fly ash [FA(20)], four of the six specimens with $40 \%$ fly ash [FA(40)], two of the four specimens with $5 \%$ silica fume [SF(5)] (only four of the six specimens initiated corrosion), one of the three specimens with $10 \%$ silica fume [SF(10)], three of the six specimens with $20 \%$ slag [Slag(20)], and two of the three specimens with $40 \%$ slag [Slag(40)]. For the specimens that repassivated, the time between first initiation and repassivation varied greatly, from 2 weeks (for Specimen SF(5)-3) to 32 weeks (for Specimen FA(40)-3). The time between first initiation and repassivation does not appear to depend on the type or amount of SCM used. The time between repassivation and final initiation also varied significantly, from 3 weeks (for Specimen SF(5)-3, which repassivated at week 94 and reinitiated at week 97) to 50 weeks (for Specimen FA(40)-4, which repassivated at week 42 and reinitiated at week 92). Here, there was also no observable link between the time from repassivation and final initiation and the type or amount of SCM used.

Figure 7 shows the average age at corrosion initiation for all specimens. For the specimens containing SCMs, two averages are presented - the average age at first initiation (for specimens that later repassivated) and the average age at final initiation. Student's t-test was used to establish the significance of the differences in initiation age, with $p=0.20$ as a threshold for significance due to the small 
Table 3-Initiation age for test specimens, weeks [Repassivation age in brackets]

\begin{tabular}{|c|c|c|c|c|c|c|c|c|}
\hline \multirow[b]{2}{*}{ Mixture designation } & & \multicolumn{7}{|c|}{ Specimen } \\
\hline & & 1 & 2 & 3 & 4 & 5 & 6 & Avg. \\
\hline $\mathrm{PC}$ & First $^{*}$ & - & - & - & - & - & - & - \\
\hline \multirow{2}{*}{$\mathrm{FA}(20)$} & First & - & $7[11]$ & - & - & - & - & 7.0 \\
\hline & Final & 30 & 23 & 28 & 28 & 47 & 8 & 27.3 \\
\hline $\mathrm{FA}(40)$ & Final & 87 & 49 & 87 & 92 & 85 & 81 & 80.2 \\
\hline \multirow{2}{*}{$\operatorname{SF}(5)$} & First & - & 一 & 92 [94] & - & - & 109 [113] & 100.5 \\
\hline & Final & 97 & 82 & 97 & - & - & 143 & 104.8 \\
\hline $\mathrm{SF}(10)$ & First & - & $19[40]$ & - & - & - & - & 19.0 \\
\hline \multirow{2}{*}{ Slag(40) } & First & - & - & 19 [24] & - & 94 [101] & - & 56.5 \\
\hline & Final & - & 81 & 47 & - & 117 & - & 81.7 \\
\hline
\end{tabular}

*Corrosion initiated followed by repassivation of the bar.

Corrosion initiated and bar did not repassivate.

Note: "- " is no initiation observed

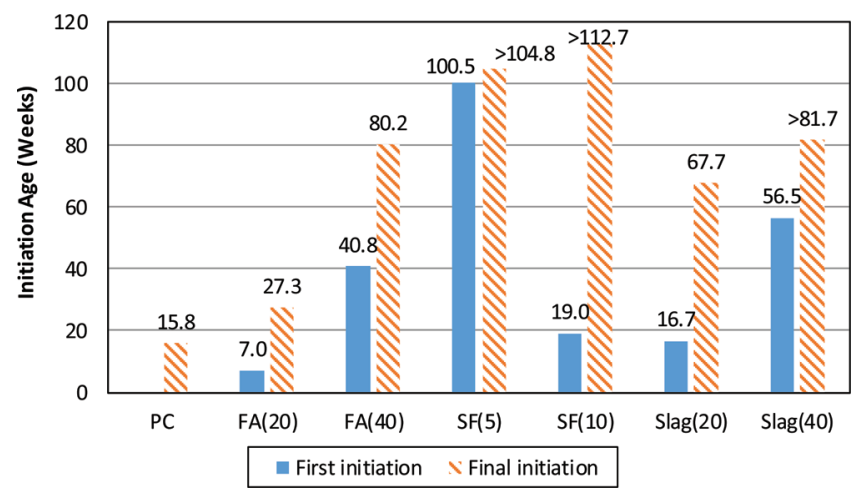

Fig. 7-Average age (weeks) at corrosion initiation.

number of specimens in each series. Note that a t-test cannot be performed on samples with a single data point, such as $20 \%$ fly ash at first initiation. As shown in the figure, some specimens containing SCMs exhibited first initiation at ages comparable to ( $20 \%$ slag cement [ $p=0.89$ ], $10 \%$ silica fume) or less than ( $20 \%$ fly ash) that of specimens with $100 \%$ portland cement. For other mixtures containing SCMs, the age at first initiation was higher than that of the $100 \%$ portland cement mixture $(p<0.065)$. In all cases, the repassivation of reinforcement in concrete containing SCM resulted in a much higher "final" initiation age - two to seven times that of the initiation age for specimens containing 100\% portland cement $(p<0.062)$. This behavior could explain the disparity in results observed in prior research - terminating a specimen at initiation of corrosion would miss the eventual repassivation of the bar that occurred in many specimens.

\section{Critical chloride corrosion threshold (CCCT)}

Figure 8 shows the average water-soluble chloride content at corrosion initiation for all mixtures. Individual critical

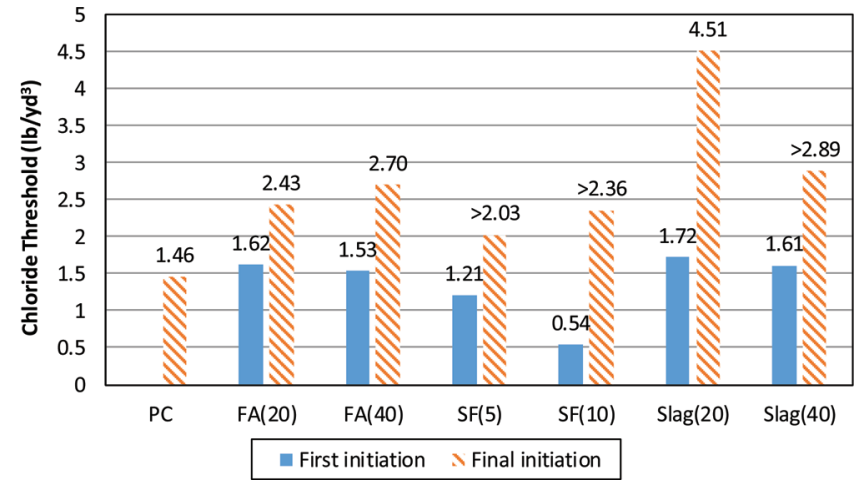

Fig. 8-Water-soluble chloride content $\left(\mathrm{lb} / \mathrm{yd} \mathrm{d}^{3}\right)$ at corrosion initiation. (Note: $1 \mathrm{lb} / \mathrm{yd} \mathrm{d}^{3}=0.59 \mathrm{~kg} / \mathrm{m}^{3}$.)

chloride corrosion threshold (CCCT) values are shown in Table 4. As discussed previously, many specimens in concrete containing SCMs repassivated after first initiation. These specimens were sampled for chlorides twice: once at first initiation and again at final initiation. Specimens in concrete containing $100 \%$ portland cement exhibited an average CCCT of $1.46 \mathrm{lb} / \mathrm{yd}^{3}\left(0.86 \mathrm{~kg} / \mathrm{m}^{3}\right)$, with no repassivation or reinitiation. Specimens containing $20 \%$ and $40 \%$ fly ash exhibited an average CCCT at first initiation only slightly greater than that of specimens containing $100 \%$ portland cement -1.53 and $1.62 \mathrm{lb} / \mathrm{yd}^{3}\left(0.91\right.$ and $\left.0.96 \mathrm{~kg} / \mathrm{m}^{3}\right)$, respectively. Student's t-test showed these differences were not statistically significant $(p=0.88$ for $40 \%$ fly ash versus $100 \%$ portland cement; a t-test could not be performed on the $20 \%$ fly ash at first initiation, as only one data point was present). After repassivation and reinitiation, however (or at final initiation for specimens that did not repassivate), specimens exhibited an average CCCT at final initiation about twice that of specimens containing $100 \%$ portland cement- 
Table 4-Critical chloride corrosion threshold (CCCT), lb/yd ${ }^{3}\left(\mathrm{~kg} / \mathrm{m}^{3}\right)$

\begin{tabular}{|c|c|c|c|c|c|c|c|c|}
\hline \multirow[b]{2}{*}{ Mixture designation } & & \multicolumn{7}{|c|}{ Specimen } \\
\hline & & 1 & 2 & 3 & 4 & 5 & 6 & Avg \\
\hline $\mathrm{PC}$ & First $^{*}$ & - & - & - & - & - & - & - \\
\hline \multirow{2}{*}{$\mathrm{FA}(20)$} & First & - & $1.62(0.96)$ & - & - & - & - & $1.62(0.96)$ \\
\hline & Final & $2.17(1.28)$ & $3.34(1.98)$ & $\ddagger$ & $2.58(1.53)$ & $2.37(1.40)$ & $1.70(1.01)$ & $2.43(1.44)$ \\
\hline $\mathrm{FA}(40)$ & Final & $1.66(0.98)$ & $1.07(0.63)$ & $2.17(1.28)$ & $3.34(1.98)$ & $3.04(1.80)$ & $4.91(2.91)$ & $2.70(1.60)$ \\
\hline \multirow{2}{*}{$\mathrm{SF}(5)$} & First & - & - & $0.89(0.53)$ & - & - & $1.52(0.90)$ & $1.21(0.71)$ \\
\hline & Final & $0.88(0.52)$ & $2.07(1.23)$ & $2.61(1.55)$ & - & - & $2.55(1.51)$ & $2.03(1.20)$ \\
\hline $\mathrm{SF}(10)$ & First & - & $0.54(0.32)$ & - & - & - & - & $0.54(0.32)$ \\
\hline \multirow{2}{*}{ Slag(40) } & First & - & - & $2.36(1.40)$ & - & $0.86(0.51)$ & - & $1.61(0.95)$ \\
\hline & Final & - & $2.56(1.52)$ & $2.94(1.74)$ & - & $3.16(1.87)$ & - & $2.89(1.71)$ \\
\hline
\end{tabular}

${ }^{*}$ Corrosion initiated followed by repassivation of bar.

${ }^{\dagger}$ Corrosion initiated and bar did not repassivate.

${ }^{\ddagger}$ Critical chloride corrosion threshold not obtained.

2.43 and $2.70 \mathrm{lb} / \mathrm{yd}^{3}\left(1.44\right.$ and $\left.1.60 \mathrm{~kg} / \mathrm{m}^{3}\right)(p=0.07$ and 0.11 , respectively). This distinction is significant, as it is the chloride content at final initiation that must be reached to achieve sustained corrosion of reinforcement, indicating a much greater time to corrosion initiation (and therefore, a much greater service life) than would be assumed if evaluation was halted at first initiation. A similar observation is made for specimens containing slag cement-at first initiation, specimens with $20 \%$ and $40 \%$ slag cement [Slag(20) and Slag(40)] exhibited CCCT values of 1.72 and $1.61 \mathrm{lb} / \mathrm{yd}^{3}$ $\left(1.02\right.$ and $\left.0.95 \mathrm{~kg} / \mathrm{m}^{3}\right)$, respectively, which is not significantly different from those of specimens containing $100 \%$ portland cement $[\mathrm{PC}](p=0.67$ and 0.85 , respectively). After repassivation and reinitiation, these specimens exhibited average CCCT values of 4.51 and $2.89 \mathrm{lb} / \mathrm{yd}^{3}\left(2.67\right.$ and $\left.1.71 \mathrm{~kg} / \mathrm{m}^{3}\right)$, respectively-two to three times greater than that of specimens containing portland cement $(p=0.002$ and 0.03 , respectively).

Specimens containing silica fume also exhibited lower values at first initiation than at final initiation; however, unlike specimens containing fly ash or slag cement, the specimens containing silica fume had CCCT values at first initiation lower than those observed in specimens containing $100 \%$ portland cement $-1.21 \mathrm{lb} / \mathrm{yd}^{3}\left(0.71 \mathrm{~kg} / \mathrm{m}^{3}\right)$ and $0.54 \mathrm{lb} / \mathrm{yd}^{3}\left(0.32 \mathrm{~kg} / \mathrm{m}^{3}\right)$ for specimens with $5 \%$ and $10 \%$ silica fume $[\mathrm{SF}(5)$ and $\mathrm{SF}(10)]$, respectively $(p=0.71$ for $5 \%$ silica fume; a T-test could not be performed on $10 \%$ silica fume specimens). After accounting for repassivation and reinitiation, the specimens containing silica fume exhibited CCCT values of $2.03 \mathrm{lb} / \mathrm{yd}^{3}\left(1.20 \mathrm{~kg} / \mathrm{m}^{3}\right)$ and $2.36 \mathrm{lb} / \mathrm{yd}^{3}$ $\left(1.40 \mathrm{~kg} / \mathrm{m}^{3}\right)$ —not significantly different from that observed for the $100 \%$ portland cement specimens ( $p=0.33$ and 0.20 , respectively).
In many cases, increasing the amount of SCM resulted in a slight to large decrease in CCCT value; all three SCMs exhibited a lower chloride content at first initiation in the specimens with the higher percentage replacement of the SCM compared with the lower percentage replacement. None of these differences, however, were found to be statistically significant (although statistical significance could not be established for the fly ash or silica fume specimens). Specimens with fly ash and silica fume exhibited an increase in CCCT at final initiation for the specimens with the higher percentage replacement, but $40 \%$ slag cement exhibited a lower CCCT at final initiation than specimens with $20 \%$ slag, a difference that was statistically significant $(p=0.09)$. Despite the lower CCCT in some cases, all specimens with the higher SCM replacement exhibited longer times to final initiation than the matching specimens with the lower SCM replacement, and all specimens with SCMs exhibited significantly longer times to initiation than the specimens containing $100 \%$ portland cement.

\section{Corrosion rate after corrosion initiation}

Figure 9 shows the average corrosion rates after corrosion initiation for all specimens; individual rates are listed in Table 5. Corrosion rates were determined based on LPR after onset of final corrosion. Reinforcement in concrete containing $100 \%$ portland cement exhibited the highest average corrosion rate: $14.4 \mu \mathrm{m} /$ year. The use of any SCM significantly decreased the average corrosion rate after initiation relative to specimens with $100 \%$ portland cement $\left(p<7 \times 10^{-6}\right)$. Generally, increasing the amount of SCM decreased the corrosion rate, although this difference was only statistically significant for specimens containing fly ash $(p=0.0021)$. Overall, specimens containing silica fume exhibited the lowest corrosion rates after initiation 
Table 5-Corrosion rate after initiation based on linear polarization resistance (LPR), $\mu \mathrm{m} / \mathrm{year}$

\begin{tabular}{|c|c|c|c|c|c|c|c|}
\hline \multirow{2}{*}{$\begin{array}{c}\text { Mixture } \\
\text { designation }\end{array}$} & \multicolumn{7}{|c|}{ Specimen } \\
\hline & 1 & 2 & 3 & 4 & 5 & 6 & Avg. \\
\hline $\mathrm{PC}$ & 11.8 & 16.1 & 15.8 & 14.9 & 14.0 & 13.6 & 14.4 \\
\hline $\mathrm{FA}(20)$ & 2.89 & 3.33 & 1.69 & 2.35 & 3.11 & 4.29 & 2.94 \\
\hline $\mathrm{FA}(40)$ & 1.09 & 1.09 & 1.83 & 1.05 & 1.76 & 1.19 & 1.34 \\
\hline $\mathrm{SF}(5)$ & 0.68 & 1.25 & 1.03 & - & - & 0.77 & 0.93 \\
\hline $\mathrm{SF}(10)$ & - & 3.05 & - & 0.58 & - & 0.49 & 1.37 \\
\hline Slag(20) & 1.39 & 0.88 & 1.43 & 1.47 & 3.34 & 1.09 & 1.60 \\
\hline Slag(40) & - & 1.26 & 1.22 & - & 0.68 & - & 1.05 \\
\hline
\end{tabular}

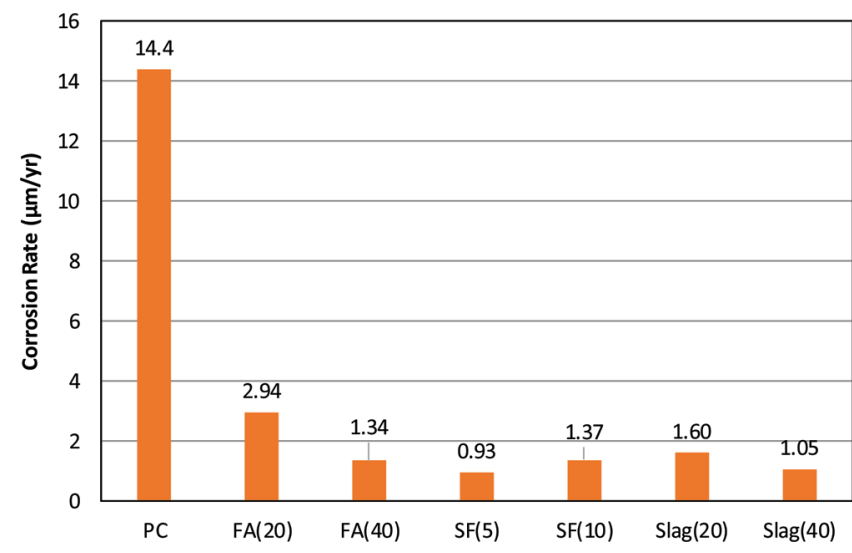

Fig. 9-Average corrosion rate after initiation based on linear polarization resistance (LPR).

(0.93 and $1.37 \mu \mathrm{m} /$ year for specimens containing $5 \%$ and $10 \%$ silica fume, respectively, followed by specimens containing slag cement (1.60 and $1.05 \mu \mathrm{m} /$ year for specimens containing $20 \%$ and $40 \%$ slag cement, respectively) and specimens containing fly ash (2.94 and $1.34 \mu \mathrm{m}$ /year for specimens containing $20 \%$ and $40 \%$ fly ash, respectively).

\section{DISCUSSION}

The behavior observed in this research program has significant implications for predictions of service life of concrete containing SCMs. In many cases, reinforcement in concrete containing SCMs repassivated after initiation; often, the reinforcement remained passive for a significant period after repassivation. Tests that terminate at or shortly after initiation may miss the repassivation; predictions based on such results may subsequently underestimate service life. This, in turn, may explain the wide variation in behavior noted in previous research on concrete containing SCMs.

Reinforcement in concrete containing SCMs exhibited longer times to corrosion initiation and lower corrosion rates after initiation than reinforcement in concrete containing $100 \%$ portland cement. The relative times to initiation reflect diffusion and absorption of chlorides into uncracked concrete. Higher replacement levels of SCMs were generally more effective at increasing time to initiation and reducing corrosion rate. The use of fly ash or slag cement also resulted in higher water-soluble critical chloride corrosion thresholds than those observed with $100 \%$ portland cement, whereas the use of silica fume resulted in chloride thresholds at final initiation comparable to those observed in $100 \%$ portland cement. It should be noted, however, that some specimens containing silica fume exhibited first initiation at a chloride threshold lower than that observed for specimens containing $100 \%$ portland cement before repassivating. Acid-soluble chloride thresholds were not examined as part of this study; results from Azad and Isgor (2016) suggest reductions in acid-soluble chloride thresholds at the higher SCM replacement levels may also occur. It should also be noted that the current study examined reinforcement in uncracked concrete.

Cracking is prevalent in many reinforced concrete structures (Schmitt and Darwin 1995; Krauss and Rogalla 1996; Darwin et al. 2010), especially in bridge decks. It shortens the time to corrosion initiation and increases the corrosion rate of reinforcing steel (Darwin et al. 2011, 2014). Lindquist et al. (2006) measured chloride contents at crack locations on bridge decks and found that the chloride content at the level of reinforcement would reach levels to cause first initiation for all the mixtures containing SCMs in this study within 36 months. SCMs would still be expected to limit the corrosion rate after initiation by inhibiting the flow of oxygen and moisture to the site of the cathodic reaction, as found by Scott and Alexander (2007).

\section{SUMMARY AND CONCLUSIONS}

The research presented in this paper examines the water-soluble critical chloride corrosion threshold (CCCT), time to corrosion initiation, and corrosion rate after initiation for conventional reinforcement in uncracked concrete containing $100 \%$ portland cement and concretes with volume replacements of cement by $20 \%$ and $40 \%$ Class C fly ash, $20 \%$ and $40 \%$ Grade 100 slag cement, and $5 \%$ and $10 \%$ silica fume. The test specimens had 1 in. $(25 \mathrm{~mm})$ concrete cover and a $w / \mathrm{cm}$ of 0.45 . The specimens were ponded with a $15 \% \mathrm{NaCl}$ solution and subjected to alternating cycles of ponding and drying following the procedures for cracked beam specimens in ASTM A955. The specimens were monitored for corrosion initiation, sampled for chloride content at initiation, and tracked using linear polarization resistance (LPR) to determine corrosion rate after initiation. For many specimens containing SCMs, repassivation occurred after first initiation; these specimens were sampled again for chlorides when corrosion reinitiated.

The following conclusions are based on the test results and analysis presented in this paper: 
1. The time to corrosion initiation for uncracked specimens containing SCMs was greater than the time to corrosion initiation for specimens containing $100 \%$ portland cement. Accounting for repassivation, the addition of SCMs resulted in ages at initiation equal to two to seven times that observed in concrete containing $100 \%$ portland cement, with concretes containing silica fume and slag cement generally having the longest times to initiation.

2. The repassivation of the reinforcement after initiation observed in specimens containing SCMs had a significant impact on the corresponding chloride threshold. For specimens containing fly ash and slag cement replacements of portland cement, the initial CCCT was similar to that for specimens cast with $100 \%$ portland cement, while the final CCCT was 66 to $200 \%$ higher. For specimens with 5 or $10 \%$ silica fume, however, the initial CCCT value was lower than that for specimens containing $100 \%$ portland cement, but the final value was higher than that for specimens containing $100 \%$ portland cement by 40 to $60 \%$. The discrepancy in the two levels of CCCT values may explain the mixed results reported in prior studies for mixtures containing SCMs.

3. Corrosion rates following final initiation were lowest for specimens containing silica fume, followed by specimens with slag, fly ash, and $100 \%$ portland cement. Increasing the amount of SCM generally lowered the corrosion rates after initiation, with most mixtures containing SCMs exhibiting corrosion rates that were an order of magnitude lower than those observed in concrete containing $100 \%$ portland cement.

\section{AUTHOR BIOS}

ACI member Matthew O'Reilly is an Assistant Professor of Civil, Environmental, and Architectural Engineering at the University of Kansas, Lawrence, KS. He received his BS in mechanical engineering from the University of Rochester, Rochester, NY, and his MS and PhD in civil engineering from the University of Kansas. He is a member of ACI Committees 222, Corrosion of Metals in Concrete, and 123, Research and Current Developments.

ACI member Omid Farshadfar is a Project Engineer with Thornton Tomasetti, Kansas City, MO. He received his PhD in civil engineering from the University of Kansas, and his BS and MS, respectively, in civil and structural engineering, from Isfahan University of Technology, Isfahan, Iran. He is a member of ACI Committee 222, Corrosion of Metals in Concrete.

ACI Honorary Member David Darwin is the Deane E. Ackers Distinguished Professor and Chair of the Department of Civil, Environmental, and Architectural Engineering at the University of Kansas and a Past President of ACI. He is a member of ACI Committees 222, Corrosion of Metals in Concrete; 224, Cracking; Subcommittee 318-B, Anchorage and Reinforcement (Structural Concrete Building Code); and Joint ACI-ASCE Committees 408, Bond and Development of Steel Reinforcement; 445, Shear and Torsion; and 446, Fracture Mechanics of Concrete.

\section{REFERENCES}

Arya, C., and Xu, Y., 1995, "Effect of Cement Type on Chloride Binding and Corrosion of Steel in Concrete," Cement and Concrete Research, V. 25, No. 4, pp. 893-902. doi: 10.1016/0008-8846(95)00080-V

ASTM A615/A615M-16, 2016, "Standard Specification for Deformed and Plain Carbon Steel Bars for Concrete Reinforcement," ASTM International, West Conshohocken, PA, 8 pp.

ASTM C39/C39M-17, 2017, "Standard Test Method for Compressive Strength of Cylindrical Concrete Specimens," ASTM International, West Conshohocken, PA, 8 pp.

ASTM C138/C138M-17a, 2017, "Standard Test Method for Density (Unit Weight), Yield, and Air Content (Gravimetric) of Concrete," ASTM International, West Conshohocken, PA, 6 pp.
ASTM C143/C143M-15a, 2015, "Standard Test Method for Slump of Hydraulic-Cement Concrete," ASTM International, West Conshohocken, Pennsylvania, 4 pp.

ASTM C231/C231M-17a, 2017, "Standard Test Method for Air Content of Freshly Mixed Concrete by the Pressure Method," ASTM International, West Conshohocken, PA, 10 pp.

Azad, V., and Isgor, B., 2016, "A Thermodynamic Perspective on Admixed Chloride Limits of Concrete Produced with SCMs," Concrete Thresholds and Limits for New Construction, SP-308, American Concrete Institute, Farmington Hills, MI, 18 pp.

Bouteiller, V.; Cremona, C.; Baroghel-Bouny, V.; and Maloula, A., 2012, "Corrosion Initiation of Reinforced Concretes Based on Portland or GGBS Cements: Chloride Contents and Electrochemical Characterizations versus Time," Cement and Concrete Research, V. 42, No. 11, pp. 1456-1467. doi: 10.1016/j.cemconres.2012.07.004

Darwin, D.; Browning, J.; O’Reilly, M.; Locke, C. E.; and Virmani, Y. P., 2011, "Multiple Corrosion Protection Systems for Reinforced Concrete Bridge Components," Publication No. FHWA-HRT-11-060, Federal Highway Administration, Washington, DC, Nov., 255 pp.

Darwin, D.; Browning, J. P.; Lindquist, W.; McLeod, H. A. K.; Yuan, J.; Toledo, M.; and Reynolds, D., 2010, "Low-Cracking, High-Performance Concrete Bridge Decks - Case Studies over First 6 Years," Transportation Research Record: Journal of the Transportation Research Board, V. 2202, No. 1, pp. 61-69. doi: 10.3141/2202-08

Darwin, D.; O’Reilly, M.; Browning, J.; Locke, C. E.; Virmani, Y. P.; Ji, J.; Gong, L.; Guo, G.; Draper, J.; and Xing, L., 2014, "Multiple Corrosion Protection Systems for Reinforced Concrete Bridge Components: Laboratory Tests," Journal of Materials in Civil Engineering, ASCE, V. 26, No. 11, Nov., pp. 1-9. doi: 10.1061/(ASCE)MT.1943-5533.0000991

Fahim, A.; Moffatt, E.; and Thomas, M., 2017, "Corrosion Resistance of Concrete Incorporating Supplementary Cementing Materials in a Marine Environment," Tenth ACI/RILEM International Conference on Cementitious Materials and Alternative Binders for Sustainable Concrete, SP-320, American Concrete Institute, Farmington Hills, MI, 14 pp.

Hussain, S. E.and Rasheeduzzafar, 1994, "Corrosion Resistance Performance of Fly Ash Blended Cement Concrete," ACI Materials Journal, V. 91, No. 3, May-June, pp. 264-272.

Krauss, P. D., and Rogalla, E. A., 1996, "Transverse Cracking in Newly Constructed Bridge Decks," National Cooperative Highway Research Program Report 380, Transportation Research Board, Washington, DC, $126 \mathrm{pp}$.

Lindquist, W. D.; Darwin, D.; Browning, J. P.; and Miller, G. G., 2006, "Effect of Cracking on Chloride Content in Concrete Bridge Decks," ACI Materials Journal, V. 103, No. 6, Nov.-Dec., pp. 467-473.

Mackechnie, J. R., and Alexander, M. G., 1996, "Marine Exposure of Concrete under Selected South African Conditions," Third CANMET/ACI International Conference on Performance of Concrete in Marine Environment, SP-163, American Concrete Institute, Farmington Hills, MI, pp. 201-214.

Mangat, P.; Khatib, J.; and Molloy, B., 1994, "Microstructure, Chloride Diffusion and Reinforcement Corrosion in Blended Cement Paste and Concrete," Cement and Concrete Composites, V. 16, No. 2, pp. 73-81. doi: 10.1016/0958-9465(94)90002-7

Oh, B. H.; Jang, S. Y.; and Shin, Y. S., 2003, "Experimental Investigation of the Threshold Chloride Concentration for Corrosion Initiation in Reinforced Concrete Structures," Magazine of Concrete Research, V. 55, No. 2, pp. 117-124. doi: 10.1680/macr.2003.55.2.117

Pal, S.; Mukherjee, A.; and Pathak, S., 2002, "Corrosion Behavior of Reinforcement in Slag Concrete," ACI Materials Journal, V. 99, No. 6, Nov.-Dec., pp. 521-527.

Presuel-Moreno, F. J., and Moreno, E. I., 2016, "Effect of Fly Ash and Silica Fume on Time to Corrosion Initiation for Specimens Exposed Long Term to Seawater," Tenth ACI/RILEM International Conference on Cementitious Materials and Alternative Binders for Sustainable Concrete, SP-320, American Concrete Institute, Farmington Hills, MI, 20 pp.

Schmitt, T. R., and Darwin, D., 1995, "Cracking in Concrete Bridge Decks," SM Report No. 39, University of Kansas Center for Research, Lawrence, KS, $151 \mathrm{pp}$.

Scott, A., and Alexander, M., 2007, "The Influence of Binder Type, Cracking and Cover on Corrosion Rates of Steel in Chloride-Contaminated Concrete," Magazine of Concrete Research, V. 59, No. 7, pp. 495-505. doi: 10.1680/macr.2007.59.7.495

Thomas, M., 1996, "Chloride Thresholds in Marine Concrete," Cement and Concrete Research, V. 26, No. 4, pp. 513-519. doi: 10.1016/0008-8846(96)00035-X 


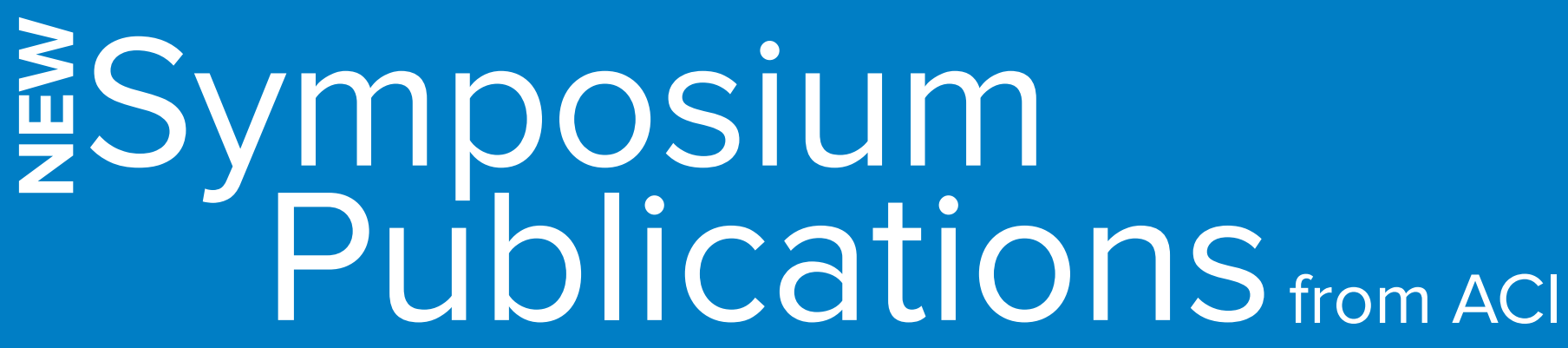

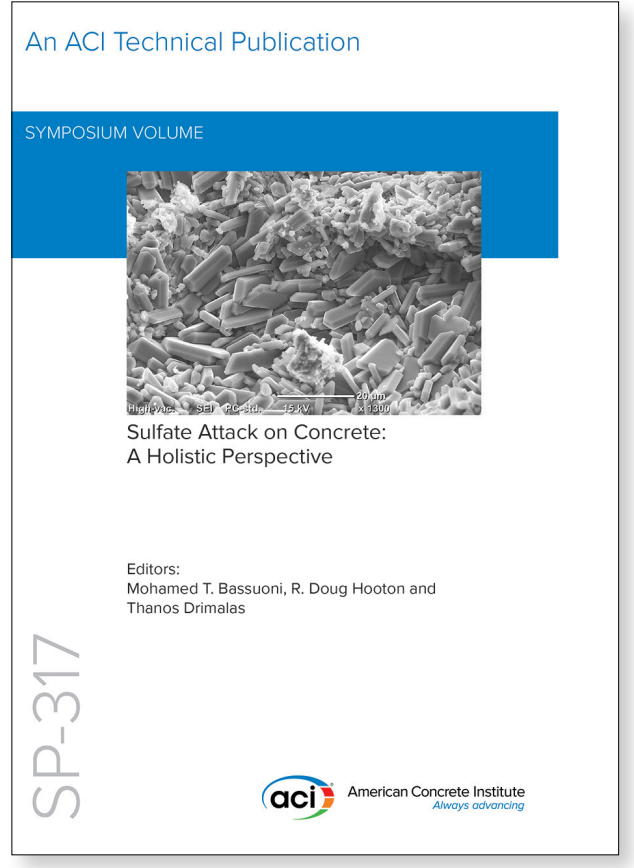

SP-317, Sulfate Attack on Concrete: A Holistic Perspective

The papers presented in this volume were included in a three-part session sponsored by ACI Committee 201, Durability of Concrete, about sulfate attack on concrete at the ACI Convention in Philadelphia, PA, on October 23-24, 2016. In line with the practice and requirements of the American Concrete Institute, peer review, followed by appropriate response and revision by authors, has been used.

Available in PDF format: $\$ 69.50$

(ACl members: \$39.00) (\$30.50 savings)

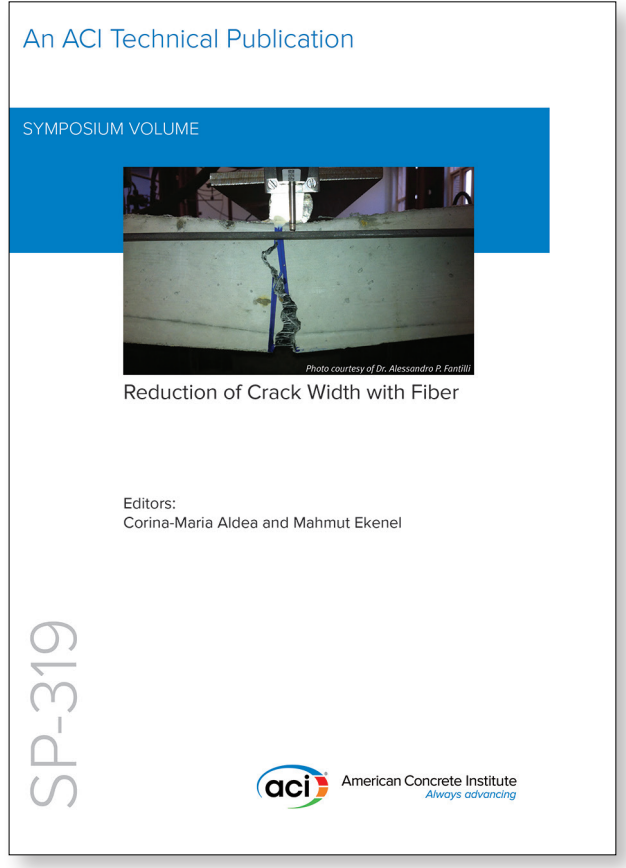

SP-319, Reduction of Crack Width with Fiber

The papers included in this special publication discuss the role of fiber reinforcement in reduction of crack width and lay the foundation for Life Cycle Engineering Analysis with fiber-reinforced concrete.

Recognizing the reduction of crack width with fibers in cement-based materials, ACI Committee 544, Fiber Reinforced Concrete, together with 544-F, Fiber Reinforced Concrete Durability and Physical Properties, sponsored two technical sessions entitled "Reduction of crack width with fiber" at the Fall 2016 ACI Convention in Philadelphia. Papers were presented by invited international experts from Belgium, France, Germany, Italy, Portugal, United Arab Emirates, and the United States.

Available in PDF format: $\$ 69.50$

(ACl members: \$39.00) (\$30.50 savings) 